\title{
Critical Resource Dependencies and the Europeanization of Domestic Interest Groups
}

\section{Jan Beyers (Leiden University) and Bart Kerremans (University of Leuven)}

\author{
Paper to be presented at the EUSA Conference in Montreal \\ May 17-19, 2007 \\ Panel 12F: Large Empirical Studies of Lobbying
}

\begin{abstract}
Although EU institutions and policies create additional opportunities for national interest groups to influence policy-making, not all domestic groups make use of the extended niche provided by the EU. Lagging Europeanization has often been explained by resource-based accounts, for instance the group's staff resources or financial strength determines the ability to Europeanize. This article explores an alternative explanation and analyzes the importance of ties that bind national interest groups to their constituencies, their critical resource dependencies and their immediate environment. Our main conclusion is that Europeanization is not just shaped by properties of the EU system, but also by the interest group's embeddedness in its immediate environment.
\end{abstract}

Acknowledgements. This paper forms part of a larger project funded by the Fund for Scientific ResearchFlanders on the political strategies of interest groups that seek access to and influence over the EU's external trade policies with regard to the WTO (G.0187.02). The project has been developed in cooperation among researchers from the University of Leuven, the Leiden University, Wissenschafszentrum Berlin and CEVIPOF Paris. The authors acknowledge the constructive comments and the feedback received from Joost Berkhout, Jan Erk, David Coen, David Lowery and the two anonymous reviewers of the Journal of European Public Policy. The paper has been published in a special issue of this journal (Vol. 14, 2007, ${ }^{\circ}$ 3, pp. 460-481).

Key words. critical resource dependencies * Europeanization * interest groups * organizational maintenance

Word count. 7874 


\section{The Europeanization of domestic interest groups}

Most studies under the heading of 'Europeanization' are concerned with how European Union (EU) institutions, politics and policies affect member states’ polities, politics and policies. Europeanization is generally referred to as the process through which key political actors such as political parties, interest groups, national bureaucracies and legislators adapt themselves to the impact of European integration (Goetz 2000; Ladrech 1994/2005; Börzel 1999; Green Cowles et al. 2001; Hanf and Soetendorp 1998; Harmsen 1999; Kassim et al. 2000; Knill 2001; Olsen 2003). Many studies on the Europeanization of interest groups suggest that this impact is largely mediated through, and conditioned by, existing domestic institutions, policies, cultures and identities (see also Sidenius 1999; Cram 2001; Beyers 2002; Eising 2003; Grote and Lang 2003; Saurugger 2005). There is no automatic shift of activities and loyalties to the European level.

For the purposes of this paper, we operationalize Europeanization with a focus on domestic interest groups. Europeanization concerns the extent to which an interest group acknowledges the impact of Europe on its substantive policy interests and/or the extent to which groups take this impact into account. Our operationalization basically concerns cognitive aspects of Europeanization, namely a disposition or a general political orientation which is coloured by the impact of Europe. It is quite similar to what Coen has labelled the 'general behavioural preferences' or the 'locus of political activity' and it fits into the more informal components of definitions offered by authors as Ladrech (Europe becomes part of the 'organizational logic') or Radaelli ('styles', 'ways of doing things', 'beliefs'..., or 'discourses’) (Ladrech 1994, 69; Coen 1997, 99-100; Radaelli 2003, 30).

One of the problems for theoretical and empirical research on Europeanization is that the key concept, Europeanization, is characterized by a product-process ambiguity (Hacking 1999, 36-8). It can be both, namely 'the process of Europeanizing' as well as the result, 'being Europeanized'. Therefore, it is difficult to distinguish dependent from independent variables or domestic from European factors. As suggested by Saurugger (2005), one way to circumvent this problem is to adopt a comparative research design which includes a micro-level analysis at the level of the interest groups themselves. 
Instead of just comparing general patterns across countries or sectors, we look at how individual organizations have adopted attitudes which are oriented towards Europe. Thereby we focus on the conditions which coincide with high or low levels of adaptation at the level of individual interest groups.

We conceive domestic interest groups as part of a European multilevel polity, which can be considered as the interest group's fundamental or potential niche, i.e. the multidimensional space in which groups flourish and survive (Gray and Lowery 1996). Theoretically, 'Europe' belongs to the fundamental or potential niche of all domestic interest groups (Ladrech 2005). However, not many organizations utilize their fundamental niche in full. Our main empirical question concerns therefore the niche that is effectively used by domestic interest groups, i.e. their realized niche. In this respect, Europeanization might also be considered as the result of a process whereby the scope of the niche in which domestic interest groups are traditionally active - or niche width expands beyond national borders. This paper is an attempt to explain variation in the extent to which different domestic groups have expanded the scope of their niche by Europeanizing themselves in response to European integration. What we illustrate is that interest groups are tied to their environment in very different ways and that their structural embeddedness has significant and substantial explanatory power for Europeanization.

\section{Conceptualization and research questions}

Some interest group researchers explain the Europeanization of interest groups by developments at the European level. European integration is an obvious factor as the expanding scope and deepening role of the EU and its institutions provides a powerful incentive for interest groups to take EU policy-making into account in their strategies and activities (Hooghe and Marks 2001, 122 and 128-9; Constantelos 2004, 1028 and 1036). This argument emphasizes the importance of rent-seeking as a motivation which drives interest mobilization. As soon as policy-outputs are created by a government institution, interests will organize and try to reap the benefits of the policy. European institutions matter as well. Their attitude vis-à-vis interest groups is affected by their informational needs and by their concern to avoid a system overload (Michalowitz 2004, 81-2; 
Broscheid and Coen 2003). Finally, much of the literature on European interest groups stresses the importance of resources. Indeed, as EU policies are often quite demanding in terms of the expertise needed to gain influence, it is reasonable to expect that especially well-endowed groups are able to make use of the opportunities provided by the European multilevel system. Disparities in resources lead to disparities in the Europeanization of interest groups. This notion strongly emphasizes the capabilities of groups to organize and extends these capabilities into the institutional nature of the EU-system which is said to disadvantage or advantage some groups compared to others.

Because Euro-level political opportunities may provide interest group with additional resources and abilities, several authors have suggested that the EU, or some of its institutions such as the European Parliament, provides opportunities for societal interests that are peripheral and weakly organized at the domestic level (Marks and McAdam 1996; Marks and McAdam 1999; Fairbrass and Jordon 2001). This enables groups to compensate their domestic weakness with Europeanization. In order to realize their objectives interest groups start to expand the scope of their activities and Europeanize their activities. Indeed, European institutions such as the European Commission and the European Parliament need information from the domestic level (technical advice, information about political support, potential compliance problems), but also domestic political players at the EU-level (ministers and bureaucrats in the Council of Ministers) are keen to stay in touch with domestic actors. Moreover, by being active on European issues domestic interest groups strengthen their domestic position as this enables them to provide crucial information to domestic public officials.

In contrast, we argue that such a compensation-effect is not necessarily the only pattern. First of all, groups may be constrained by factors that are situated at the European level. Imig and Tarrow suggest that norms of appropriateness with regard to the action repertoire advantage especially 'orderly, institutional and representative approaches' and thereby excludes groups that rely on contentious politics $(1999,130)$. Constraints may also exist at the domestic level. Several authors have tried to identify such constraints and their impact on the propensity of national interest groups to Europeanize. Eising and Kohler-Koch for instance, refer to the 'Beharrungsthese' (obstinacy thesis) where a negative correlation is found between the extent to which a 
group is integrated in domestic policy networks, and the extent of its integration in Europeanized networks (2004, 46; see also Sidenius 1999; Cram 2001; Eising 2003). In the same vein, Cram points to the relationship between domestic institutions and interest groups (preferential, selective, pluralist) on the likelihood that the latter will stick to their domestic polity (2001, 609-10). Schmidt points to the fact that national polities act as a potential learning school for the development of skills that are particularly important at the EU-level and explains differences by considering variance in this regard (1999, 1645; see also Coen 1998, 93; Eising 2004, 231). In an earlier paper, Beyers demonstrated that the Europeanization of network-strategies of domestic interest groups follows a cumulative pattern (2002, 601-3). In general, networking among domestic interest groups prevails and seeking access to national officials, especially the national government, is crucial. It is only after the establishment of domestic networks that interest groups start to extend their networks to the European level.

In addition, many interest groups depend primarily on domestic institutions in order to realize their goals. Such groups have no need or incentive to Europeanize. Indeed, quite some policy areas - such as social welfare provision, cultural policy, and labor market regulation - are still excluded from the EU agenda. Therefore, in many cases Europe is not an alternative, but something that can be complementary to an ongoing process of interest mobilization (Ladrech 2005). This implies that, adaptation or Europeanization will depend on their immediate organizational environment. Moreover, Europeanized domestic interest groups may even strengthen their domestic position if they maintain their domestic networks.

Our argument is thus that Europeanization is shaped by the immediate organizational environment of domestic groups. It ties into a more general theoretical account on critical resource dependencies. Most organizations are not internally selfsufficient and maintaining sufficient resources is a daily concern for them (Bouwen 2002). Organizations extract resources from their environment, resources that are supplied by other actors such as government subsidies, membership fees or gifts and donations. Gaining resources is costly and demanding. It requires an investment and interactions with actors providing such resources. It is important to note that gaining resources through exchange networks has rather ambiguous consequences for the actor's 
autonomy. On the one hand, extracting resources from the environment can be seen as something that strengthens the actors' position vis-à-vis others as more resources lead to more capabilities. On the other hand, resource dependencies can also be considered as something that reproduces or even strengthens existing dependencies. As Pfeffer and Salancik write: '(..) acquiring resources means the organization must interact with others who control those resources. In that sense, organizations depend on their environments' $(1978,258)$ and, therefore, 'what happens in an organization is not only a function of the organization, its structure, its leadership, its procedures, or its goals. What happens is also a consequence of the environment and the particular contingencies and constraints deriving from that environment' $(1978,3)$. In this sense, gaining resources decreases autonomy and the propensity to expand the scope of attention towards policies and institutions which transcend the national level. This is especially the case when it concerns critical resource dependencies. As Pfeffer and Salancik indicate: 'Criticality measures the ability of the organization to continue functioning in the absence of the resource (..)' $(1978,46)$. The major weakness of a simple resource-based perspective that ignores critical resource dependencies is that it assumes that interest groups are always prepared to modify and Europeanize their strategies as soon as their material self-interests would require or their resources would enable them do so. Such a perspective neglects the possibility that actors refrain from going beyond the domestic level, because they are in need of, identify with or are loyal to their local or domestic resource suppliers. ${ }^{i}$

Even tough it is often argued that especially resourceful organizations Europeanize, we argue that it is not necessarily size or resources that matter. More important is how organizations are structurally connected or tied to their environment. In particular, we emphasize how strongly an organization depends on its members/constituencies for its survival, the sector in which its main activities are located, and how dependent an organization is on sponsors in their immediate environment. For the moment, we identify three key factors - members/constituents, resource dependencies, and sector - , which will be analyzed in the empirical sections below.

First, the relation between interest groups and members/constituencies is crucial. Does the interest group depend on its members and constituencies for its survival? The more an interest group relies on individual members to carry out management functions, 
and to help with campaigning, the more this group needs to be locally embedded in order to recruit these people. Then, a well-elaborated local network is needed in order to recruit, thereby creating the probability that organizations will be weakly oriented towards Europe. Also, if organizations have as their main task to deliver specific services or benefits to their members, they will be more locally embedded and relatively weakly Europeanized. Some benefits will constrain Europeanization as they may require an interest group to focus on one political system (for instance getting subsidies). Social security and welfare provisions supplied by domestic agencies are cases in mind. Advocacy with regard to policy areas where competencies are divided between the member states and the EU (see the third point) stimulates domestic groups to take a multi-level approach into consideration.

Second, the exclusivity of monetary resources can be quite relevant for an organization too. Cram, for instance, refers to the issue of funds organizations gain from domestic sources (Cram 2001). She argues that national organizations that receive large amounts of money from their national government are not very autonomous; but that the other extreme, i.e. no funding at all, prevents organizations to carry out their tasks. In the latter case, the lack of funding explains the lack of Europeanization (as well as domestic political activity) while in the former case it explains the key attention organizations have for domestic institutions. So one of our questions concerns whether groups gain money from various sources and/or whether groups depend strongly on one kind of source. If one domestic funding source is predominant, does it concern government subsidies, individual membership fees or other sources of income? The dependence on domestic public institutions is a factor that affects the absence or presence of exit options and the potential Europeanization of an interest group. The more domestic interest groups depend on resources exclusively provided by government agencies such as subsidies, the more these groups restrict their actions to the domestic political system.

Third, the importance of domestic constituents is to a large extent affected by the policy-sector in which an actor is active. Research carried out by Bennett among firms provides some clues. He has shown that businesses differ with respect to the political route they choose in response to the geographical location of their main interests (Bennett 1999). Firms that are situated in a sector that is weakly internationalized, in which 
domestic protection (for instance through regulation or redistributive policies) plays a major role, where industry is concentrated in one country, or where there are clear national interests, were more likely to rely on national modes of interest representation instead of European ones. Such firms were also less likely to Europeanize their strategies. A similar argument applies to how policy competencies are divided within the EU. Some interest groups are active in policy domains where EU competencies are weak or nonexistent and where most policy benefits are realized by national governments. Such groups will not need to Europeanize, while groups that are active in strongly Europeanized sectors will ceterus paribus adapt more.

\section{Research design}

The dataset we use is part of a larger research project on how interest groups interact with public actors in four EU member states - Belgium, France, Germany and the Netherlands - as well at the EU-level. The focus of the project is thereby on the efforts these groups make to influence the EU's external trade policies in the World Trade Organization (WTO), more particularly in the areas of agriculture, steel/metal and services. One part of this larger project tries to find out whether and how national interest groups have Europeanized their political strategies. Data collection has been based on an elite-survey conducted between May 2003 and February 2006.

One of the problems with elite-surveying concerns the identification of a relevant sample of interest groups. As part of the research questions can only be dealt with in a comparative design, cross-sectional samples that are structurally equivalent and comparable across countries are needed. For each country and the EU-level we aimed at a final sample of 120 completed interviews; 20 with public officials and 100 with interest groups. ${ }^{\text {ii }}$ In addition to this we tried to get a diverse sample with a large variety of interest groups including NGOs, public interests, business interests and labor interests. Basically, our sample is constructed on the basis of a positional sampling technique for which we screened a large amount of formal sources. ${ }^{\text {ii }}$

The established list, however, does not correspond with a balanced cross-sectional sample that is structurally equivalent across countries. Regarding sectoral business and labor interests we only retained those sectoral associations that have a direct 
(agriculture/food industry, metal/steel, services) or an indirect link (transport and retailing/distribution) with the policy sectors under investigation. NGOs were retained in the sample as well as cross-sectoral specific interest groups such as cross-sectoral employer unions, trade unions and associations representing small and medium enterprises (SME's). Several steps were taken to avoid a biased sample with regard to access and mobilization; less visible and less active organizations run the risk to be excluded. This risk was particularly high for trade unions. Although trade unions play an active part in domestic politics (especially in neo-corporatist countries such as Belgium, Germany, or the Netherlands), they were barely named in the sources mentioned above (Beyers and Kerremans 2007). In order to redress this potential bias, we proceeded as follows: First, for all international and European umbrella organizations mentioned in one of the above sources, we checked whether or not their European or domestic members were already included. If not, they were added. Second, for the three policy sectors, we investigated the potential cleavages so that our sample would include varying and/or opposing policy positions. In order to identify the actors connected to these cleavages we used the relational data-set compiled by Bernhard Wessels (Wissenschaftzentrum Berlin) which links Euro-level associations to their domestic members (Wessels 2004). Finally, we consulted a number of experts (especially with respect to trade unions) and checked the composition of key advisory bodies at the domestic and the EU-level (such as the EU's Economic and Social Committee) in order to fine-tune the sample with regard to trade unions.

Table 1 gives an overview of the results of the fieldwork regarding the interviews with interest group officials in the four countries. ${ }^{\text {iv }}$ We make a rough distinction between a) NGOs or public interest groups, b) economic/business and employers and c) trade unions. The first group consists of environmental NGOs, consumer NGOs, development NGOs and a small number of women's organizations or organizations representing protest movements. The second group contains cross-sectoral business associations, sectoral business associations (primarily in the field of agriculture, services and metal/steel) as well as small 'businesses' such as farmers, professions and small and medium enterprises. Under the category of trade unions we find both cross-sectoral and sectoral employers' associations. Although this categorization conceals much 
heterogeneity, it will be demonstrated below that much variation in the sample corresponds to this rough distinction.

\section{INSERT TABLE 1 HERE}

Interviews were conducted on the basis of a standardized questionnaire with almost all questions being closed. Key parts of the questionnaire dealt with different characteristics of the political system within which the actors operate, the policy positions of actors with respect to twenty policy issues, their political strategies (including both traditional forms of lobbying as well as outside lobbying) in relation to these issues, the resources actors had at their disposal and invested in political activities, and their embeddedness in domestic and/or European policy networks. In this article only a small subset of the variables will be used, namely those variables related to resource dependencies and Europeanization.

\section{Findings}

We focus the analysis on the relationship between the level of Europeanization on the one hand, and the following variables on the other hand: (a) the type of interest group; (b) the nature and the extent of the group's resource dependencies; and (c) the policy domains in which these groups have an interest. In the first part of the analysis we describe how different interest groups show a different level of Europeanization. Then we investigate the critical resource dependencies of different sorts of interest groups. Finally, we correlate resource dependencies and policy sector interest with the extent to which groups are Europeanized.

As indicated above, we operationalize Europeanization as the extent to which an interest group acknowledges the impact of Europe and/or the extent to which a group takes this impact into account. We asked each organization official to what extent their focus of attention is directed towards EU policies, the impact of EU-level decisions on the organization, and the extent to which the organization monitors EU policies. It appears that EU policies are generally seen as having an important impact on most organizations (between 69 and 88 percent, table 2). However, there are significant 
differences between the four countries. Compared to their Belgian and Dutch counterparts, more German and French groups claim to experience a marked impact and more German and French groups monitor European policies. We also asked our respondent to indicate the percentage of their overall time and energy, expressed on a scale from 0 to 100, they spend on European policies. These data indicate that on average, German and French interest groups pay more attention to Europe than Belgian and Dutch groups (figure 1).

The last three columns in table 2 shows the same data, but now cross-tabulated with the interest group type. Here, it appears that especially employers interests show a high level of Europeanization compared to public interests and trade unions. The differences between trade unions/NGOs and employers interests are often up to 30 percent. This observation is confirmed when we compare time and resources spent on European policies across countries and interest group types. Employers or business interests are the most Europeanized everywhere. Only in Germany do we observe quite Europeanized trade unions, compared to Belgium, France and the Netherlands. As will be demonstrated below, some of these differences correspond to varying resource dependencies.

\section{INSERT TABLE 2 AND FIGURE 1 ABOUT HERE}

A factor analysis of these four variables results in a single-factor solution with an eigenvalue of 1.58 (39 percent of the total variance). The lower the factor scores, the more Europeanized groups are. Note that the distributions within the four member states on these factor scores fit into the pattern described above. Note also the differences across the four countries (figure 2). Groups in the two larger member states tend to be more Europeanized than their counterparts from the smaller member states. Further, the differences within Belgium and the Netherlands are considerably higher than the differences within France and Germany, something that is indicated by the standard deviations for Belgium (.87), the Netherlands (.88), Germany (.73), and France (.69). 
In sum, the differences between the group types and the four countries are quite considerable. Our next step consists of analyzing the critical resource dependencies of the interest groups across the four countries. Table 3 shows the result for five potential income sources: (1) individual membership contributions and individual donations, (2) membership fees from companies, (3) government subsidies, (4) income from economic activities (such as the payments for services, revenue generated by the sale of goods, and the returns of investments and savings...), and (5) income from institutions and organizational entrepreneurs (such as donations by firms, organizations, or charities). Table 4 should be read as follows: 82 percent of Belgian NGOs get their funding from government subsidies and among these 82 percent, government subsidies represent an average share of 57 percent of their budget.

In table 3 it becomes immediately clear that organizations differ a lot in terms of their critical resource dependencies. Let us start with the trade unions: in each of the four member states, they prove to be extremely dependent on individual contributions. Between 60 and 96 percent of the trade unions rely on the payment by their individual members of membership fees. On average, these fees account for 64 and 96 percent of their overall budget. NGOs, in contrast, have a more diversified structure of income. A large majority of them depends on government subsidies. This dependency is much higher in Belgium and the Netherlands than in Germany and France. In the small countries, 76 and 82 percent of the NGOs depend on such subsidies, which represent an average of 57 to 59 percent of their overall budget. In Germany and France, 68 percent of NGO's rely on this source, which accounts for between 42 and 45 percent of their overall budget. Given these results, one could plausibly claim that the Belgian and Dutch NGO's are more critically dependent on government subsidies than NGOs in France and Germany. The picture is reversed for individual membership contributions. The lower reliance of French and German NGO's on government subsidies is compensated by a higher dependency on individual membership contributions (up to 48 percent of their overall budget).

INSERT TABLE 3 HERE 
Finally, business interests and employers associations show an even higher level of diversity in their sources of income. What is striking here is the low dependency on membership fees paid by companies. Although more than 50 percent of the organizations receive an income from such fees, this source represents less that 10 percent of their budget on average. Quite a substantial share of the business associations depend on fees paid by individual members but this dependency is less substantial than the trade union's dependency on such fees. Yet, a substantial difference exists between the small and the large member states. In the small member states individual membership fees tend to be much more important for the average business association than in the larger ones.

Now that we have compared the critical resource dependencies of different interest groups, it is important to look how these groups perceive these dependencies. Perceptions on such dependencies may matter a lot in the choices organizations make on their activities and in the extent to which concerns about organizational maintenance guide these choices. For that purpose a question was asked about how organizations experience the competition for budgetary resoures. Does the organization experience much competition from others and if so, how strong is this competition perceived to be? Table 4 compares the perceived level of budget competition for the three types of interest groups and for each of the four countries. One of the first things that strike the eye is that those organizations that have the most diverse stream of income and that are the least dependent on their critical constituency, such as employers' organizations, perceive on average the lowest level of budget competition. On average, NGOs and, especially, trade unions are much more likely to experience 'moderate' or 'strong' competition for budgetary resources.

\section{INSERT TABLE 4 HERE}

However, there are considerable differences among trade unions. The German trade unions are somewhat atypical as they demonstrate a much lower level of perceived budget competition, compared to the French, Dutch and Belgian trade unions. This might be due to the fact that the German trade union system is much more centralized and that 
one German trade union - the Deutscher Gewerkschaftsbund - occupies a representation monopoly within the German neo-corporatist constellation. Therefore, it does not experience a high level of competition, at least not as far as individual member contributions are concerned. Belgium and the Netherlands have a more fragmented trade union system with three trade unions each representing a substantial part of labor. In Belgium and the Netherlands, no single organization has been able to dominate the niche of labor representation. France, in contrast, combines a highly fragmented system of ideological radicalism with a low level of unionization. Given the high number of trade union organizations in France and given the fact that each trade union seeks to maintain its own ideological niche, it seems reasonable to assume that the French unions develop their own specialized ideological niche. This might explain why the average French trade union perceives less competition compared to Belgian and Dutch trade unions.

What is the relationship between, on the one hand, perceived competition and resource dependencies and, on the other hand, the levels of Europeanization? As indicated above, given the fact that monitoring European policies is quite demanding it is plausible to expect a relationship between Europeanization and resources and resource dependencies. Yet, a comparison of table 3 and 4 with the data on Europeanization in figure 1 and 2 suggests that a low level of perceived budget competition corresponds with a lower dependency on a critical resource provider as well as with a more Europeanized orientation among interest groups. This seems to happen with regard to business interests, but also to some extent with regard to the French and the German trade unions. Conversely the Dutch/Belgian NGOs and trade unions combine a high level of perceived budget competition with a strong dependency on one critical resource (government subsidies or individual membership fees). Typically, their level of Europeanization is low.

We measured the amount of resources in two ways. One consists of the size of the available budget, but the problem with this measure is that many respondents refused to answer to this question. The other measure consists of the number of full-time equivalents (FTE) employed. Here we have complete data and the high correlation with budget size ( $\mathrm{r}=.89, \mathrm{p}=.0001)$ suggests that staff can be considered as a valid indicator of a group’s resources. Table 5, first row, provides the correlations of this variable with the 
level of Europeanization. No significant correlations can be found, except in the case of Germany where we observe a small slightly significant correlation between a large staff resource and a higher level of Europeanization. In contrast, we find substantial correlations between the perceived level of budget competition and Europeanization for Belgium, the Netherlands and Germany. In the case of France, there is, probably due to a low standard deviation, no substantial association. These results indicate that high levels of perceived budget competition correlate with low levels of Europeanization. Interest groups that perceive severe competition feel themselves more vulnerable in terms of their organizational maintenance; these groups tend to be less Europeanized. It is useful then to take a closer look at these critical dependencies and their relationship with Europeanization. The remainder of table 5 provides the necessary information.

As is indicated by this table, we observe statistically significant correlations of individual membership contributions, company membership contributions, and government subsidies with Europeanization. However, the results for individual membership contributions are unclear. German organizations that depend on individual membership fees are less Europeanized than those that do not, but this pattern is repeated in no other country. In the case of France, a growing importance of individual membership contributions in the overall income of interest associations corresponds with declining levels of Europeanization. In Belgium, the opposite takes place. There, a rising importance of individual contributions as a source of income corresponds with higher levels of Europeanization.

The results with respect to company membership contributions and government subsidies are more straightforward. These confirm some of our earlier observations. Organizations that depend on company membership contributions are more Europeanized, a finding which reflects the fact that their constituents - business - are strongly Europeanized too. Important here is that dependency in terms of the proportion of company membership contributions to the organizations' overall budget has no effect on Europeanization. Consequently, the critical nature of this resource in comparison with others cannot be considered to be a factor in the Europeanization behavior of these organizations. Whether or not this resource is critical, business associations are highly Europeanized. 


\section{INSERT TABLE 5 HERE}

Again with the exception of France, organizations that depend on government subsidies are less Europeanized. Moreover, in Belgium and the Netherlands, the countries where many organizations (especially NGOs) are highly dependent on government subsidies, we find that the larger the share of government subsidies in the organization's budget, the less the interest group is Europeanized. This suggests that rather than the type of organization, the provider of its critical budgetary resource matters. And in the case of Belgian and Dutch NGO's, national governments are the providers. Clearly, they do not provide such subsidies for altruistic reasons. As neo-pluralists would claim, they do so because they believe that imbalances in the national interest group system need to be corrected. And when they assess such imbalances, they use a national perspective. Interest associations that depend on government subsidies know this. As a consequence, they will prioritize their immediate national environment in the first place. Less time and energy will be left to focus on Europe. At a more general level, these findings confirm that organizational maintenance and critical resource dependencies are crucial factors for understanding the Europeanization of national interest organizations.

Our final research question concerns the policy domains in which an interest group claims to have the most interest. In order to be successful interest groups need to realize benefits for their members and constituents. For some interest groups these benefits need to be realized at the European level, while for others benefits must be realized at the domestic level. Presumably, groups with a large stake in the social security sector or labor market regulation and organizations whose influence activities affect the welfare benefits of their clients - for example trade unions - focus more on the policy level where key decisions with regard to social security and labor market regulation are taken. In contrast, national business organizations increasingly represent transnational and European companies that are active within the borders of a member state. These groups depend for the well-being of their constituents on how the European internal market operates. Being active in and being dependent on the international economy fosters Europeanization. In addition to the interest in a specific policy domain we 
hypothesize that Europeanization relates to the organization's expansiveness. One could argue that Europeanization occurs especially among those organizations that are able to expand the scope of their policy interest, i.e. interest groups that are multiple niche players and have a broad niche width.

During the interviews the respondents were asked to screen a list with policy areas in which they could be active. For each area the respondent was asked to indicate how important this particular policy area is for the organization. 'Importance' was defined as 'having invested many resources in this particular policy domain (for example in terms of research, hiring staff...)' and respondents scaled importance on a 5-point score, a low score implying high levels of interest. Consequently, a positive correlation between importance attributed to a policy area and 'Europeanization’ means that being active in a specific policy area contributes to the Europeanization of an interest group. In addition, we create a variable, scope of policy, which simply measures the number of policy areas in which an interest group claims to be active. Accordingly, a negative correlation indicates that a large niche width corresponds to Europeanization.

\section{INSERT TABLE 6 HERE}

Table 6 shows the results and indicates that the division of competencies between the EU and the member states affects the Europeanization of national interest groups. The substantial correlations for competition policies, export policies and environmental policies illustrate that these are, at least among interest groups, highly Europeanized policy areas. Similar observations, although less pronounced in terms of correlational strength (especially for France), can be made for consumer policy, industrial policies, and research and development. So groups that are active in policy sectors with some substantial and significant EU competencies show higher levels of Europeanization.

For policy areas that are highly dependent on governmental regulations, subsidies and allowances such as social security, employment policy, media and cultural policy, we observe no significant relation between importance and Europeanization. Table 7 also shows, however, that there are significant differences among the four member states. The same holds for the correlation between scope of attention and the level of 
Europeanization. The results indicate that a broader scope of attention tends to result in higher levels of Europeanization, with the relation being substantially higher in the case of the Netherlands, and substantially lower in the case of France. The moderate and sometimes low value of the correlation coefficients - even in some sectors where the EU has substantial competencies such as agriculture and fisheries - equally suggests that even in cases where interest groups consider these policy sectors to be important, Europeanization does not automatically follow.

These results confirm our third proposition, namely that Europeanization is considerably constrained by a dependence on domestic policies. When we look to the type of groups interests in the least Europeanized policy areas we find predominantly labor unions; between 77 and 98 percent of the interviewed trade union officials claimed to be interested in social security, labor market regulation, and fiscal policies. In contrast, the interest for these policy areas is much lower among NGOs, but also among employers interest (here between 25 and 40 percent of the interviewed groups claimed to be 'interested' or 'strongly interested').

\section{Conclusions}

The good news that comes out of this article is that Europeanization is not necessarily a privilege for large and resourceful organizations that are able to Europeanize. In this regard, we have to be careful with far-fetched conclusions in terms of resources driving the process toward Europeanization. Although, our empirical results do not reject the notion that EU-level opportunities stimulate Europeanization, our findings illustrate that Europeanization is much more complex and contextualized than the mere existence of European stimuli.

Although a dependency on individual members and constituents has no direct relation with our dependent variable, we showed that especially trade unions that depend strongly on individuals and that operate in a context with higher levels of perceived budget competition - namely in Belgium, the Netherlands and France - were less Europeanized than German trade unions which are more monopolistic. The perception of budget competition and critical resource dependencies are more salient than resources as such. With regard to critical resource dependencies, we observed that especially a 
dependency on government subsidies constrains Europeanization. This correlation is most pronounced in Belgium and the Netherlands, two countries where the organizations that depend considerably on subsides, namely NGOs, experience severe competition for budgetary resources. Finally, we observe that policy domain matters. Some interest groups are strongly tied to policy sectors where EU competencies are weak or nonexistent and where most benefits are realized by national governments These groups are less pressured to Europeanize, not because they do not have resources or because they do not appreciate potential European benefits, but simply because they are still able to realize many of their political goals at the domestic level.

In contrast to some of the existing literature we stress the fact that it is not necessarily ‘Europe’, i.e. the European institutions, or the resource endowment of interest groups that shapes their Europeanization. Without denying the potential importance of the role played by resources and EU-level opportunity structures, we demonstrated that an interest group's embeddedness in its immediate environment as well as critical resource dependencies play a crucial role. Although the EU creates many new opportunities for domestic groups to adapt, Europeanization is not a natural or immediate response. Thus, instead of a logic of influence (for instance, exercising influence, designing political strategies and exploiting political opportunities), our analysis emphasizes that the Europeanization of interest groups is substantially shaped by factors related to the group's immediate environment which affects its organizational maintenance. Such factors may relate to members (for instance, a dependence on membership dues), or to sponsors (for instance, a dependence on government subsidies) (see also Schmitter and Streeck, 1999; Michalowitz, 2004).

We started from the general notion that the Europeanization of domestic interest groups can be explained by investigating the link between the interest characteristics and the immediate organizational environment of these groups. The empirical results show that in addition to the potential impact of the EU institutions themselves, more research attention has to be paid to the immediate context of a group and more in particular their critical resource dependencies. True, our empirical results remain somewhat illustrative and explorative. Detailed theory-driven case-studies are needed in order to enrich and refine some of the more general conclusions we arrive at. Second, we have neglected 
concrete political behavior, political strategies and tactics. In order to rebalance the underestimation of organizational maintenance without ignoring the relevance of the external political environment, more detailed research on the relation between specific political strategies and critical resource dependencies might be fruitful. 
Table 1. Overview of the sample and fieldwork results (Belgium, Netherlands, Germany and France)

\begin{tabular}{lccccc}
\hline & Belgium & Netherlands & Germany & France & Total \\
\hline NGOs/public interests & & & & & \\
- sample & 53 & 37 & 36 & 38 & 164 \\
- n response (\%) & $44(83 \%)$ & $34(92 \%)$ & $28(78 \%)$ & $34(89 \%)$ & $140(85 \%)$ \\
$\begin{array}{l}\text { Economic/business/employers } \\
\text { - sample }\end{array}$ & 87 & 65 & 73 & 78 & 303 \\
- n response (\%) & $80(92 \%)$ & $57(88 \%)$ & $52(71 \%)$ & $62(79 \%)$ & $251(83 \%)$ \\
Trade unions & & & & & \\
- sample & 29 & 18 & 13 & 36 & 96 \\
- n response (\%) & $24(83 \%)$ & $16(89 \%)$ & $10(77 \%)$ & $32(89 \%)$ & $82(85 \%)$ \\
\hline Total & 169 & 120 & 122 & 152 & 563 \\
- sample & 148 & 107 & 90 & 128 & 473 \\
- n response (\%) & $(88 \%)$ & $(89 \%)$ & $(74 \%)$ & $(84 \%)$ & $(84 \%)$ \\
\hline
\end{tabular}


Table 2. Europeanization of interest groups, countries and type of interest group (percentages)

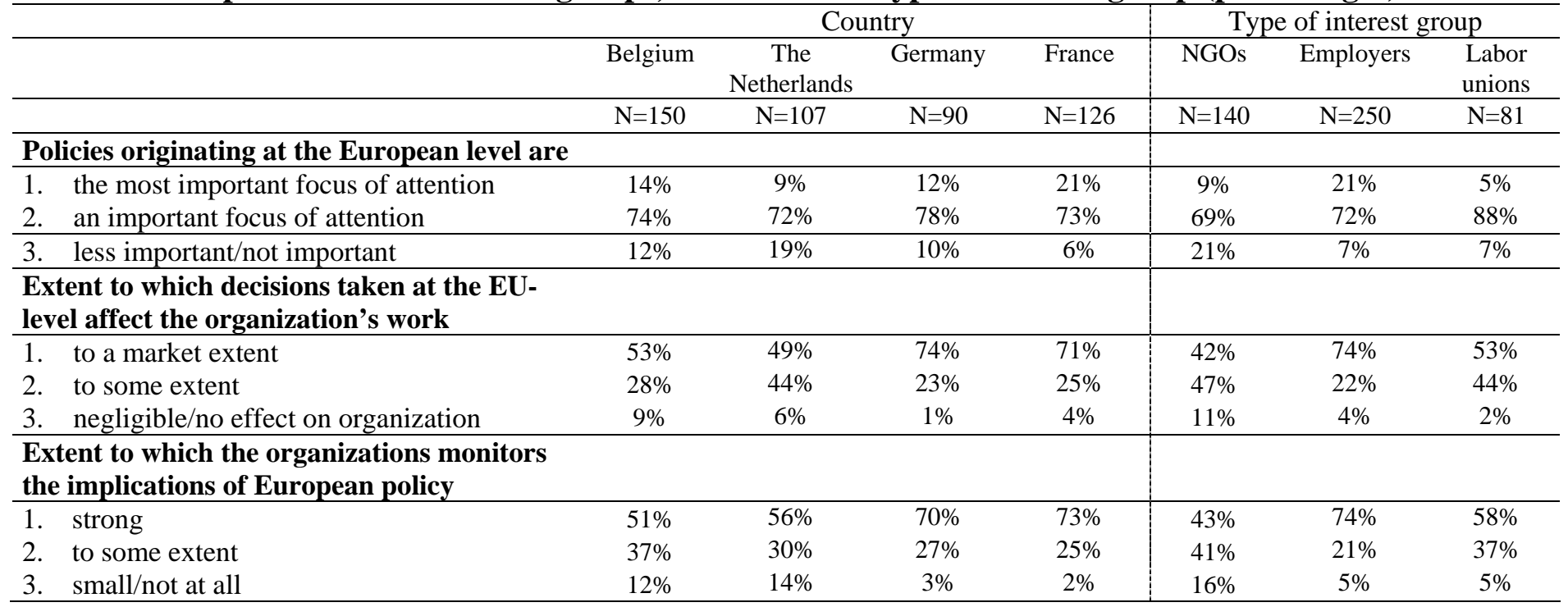


Figure 1. Percentage of time and energy spend on Europe

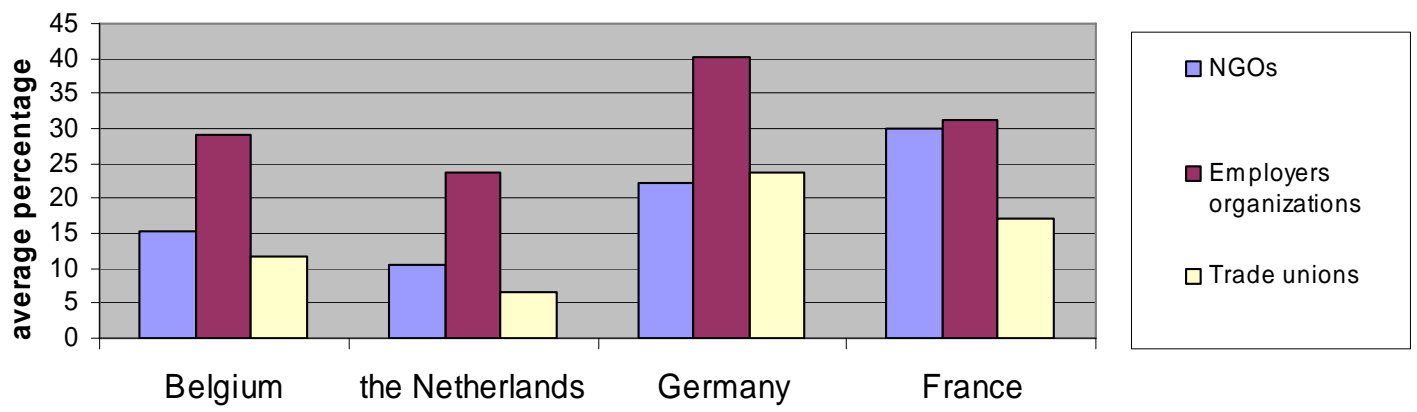

Figure 2. Level of group Europeanization compared between countries (average factor scores)

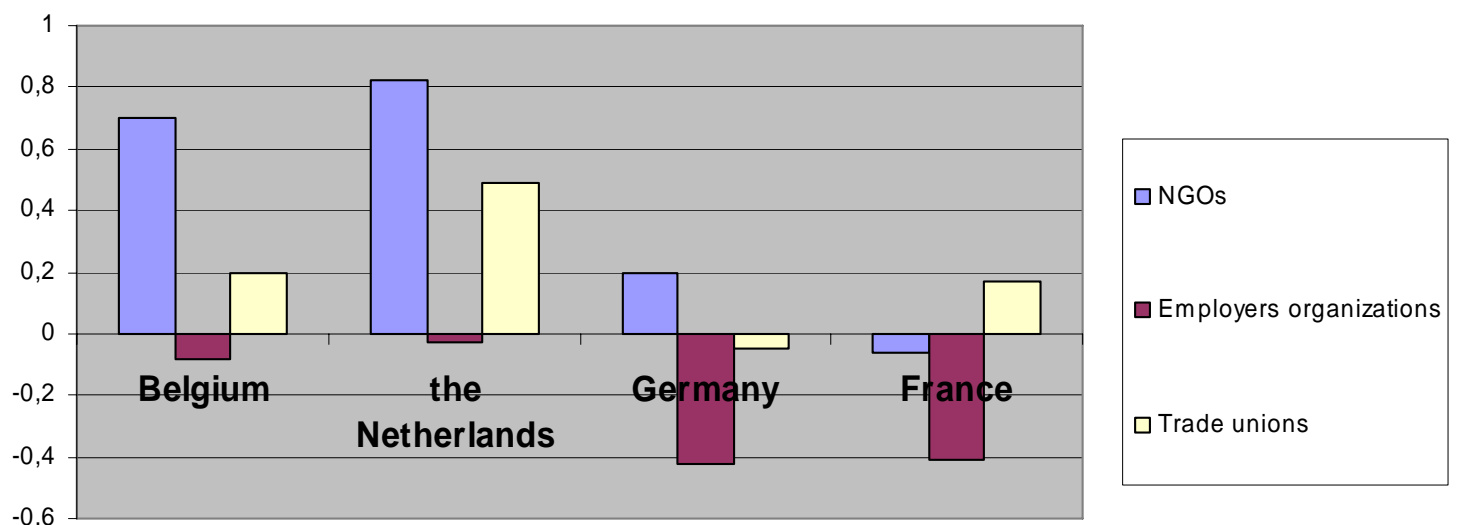


Table 3. Critical resource dependencies (percentage of organizations depending on a particular resource and the share of the budget)

\begin{tabular}{lcccc}
\hline & Belgium & The Netherlands & Germany & France \\
\hline NGOS & & & & \\
\hline individual membership & $79 \%$ & $50 \%$ & $75 \%$ & $79 \%$ \\
company membership & .33 & .36 & .48 & 0.44 \\
& - & $12 \%$ & $4 \%$ & $12 \%$ \\
government subsidies & - & $<0.10$ & $<0.10$ & $<0.10$ \\
& $82 \%$ & $76 \%$ & $68 \%$ & $68 \%$ \\
economic activities & .57 & .59 & .42 & .45 \\
& $52 \%$ & $50 \%$ & $43 \%$ & $35 \%$ \\
institutions/entrepreneurs & .20 & .18 & .12 & .16 \\
& $50 \%$ & $68 \%$ & $64 \%$ & $62 \%$ \\
Business interests & .13 & .17 & .22 & .20 \\
\hline individual membership & & & & \\
& $35 \%$ & $37 \%$ & $17 \%$ & $17 \%$ \\
company membership & .66 & .60 & .24 & .34 \\
& $51 \%$ & $61 \%$ & $69 \%$ & $59 \%$ \\
government subsidies & $<0.10$ & $<0.10$ & $<0.10$ & $<0.10$ \\
& $27 \%$ & $21 \%$ & $12 \%$ & $33 \%$ \\
economic activities & .29 & .30 & .45 & .38 \\
institutions/entrepreneurs & $52 \%$ & $59 \%$ & $48 \%$ & $31 \%$ \\
& .26 & .22 & .14 & .25 \\
Trade unions & $31 \%$ & $33 \%$ & $50 \%$ & $48 \%$ \\
\hline individual membership & .52 & .32 & .45 & .43 \\
\hline company membership & & & & \\
& $96 \%$ & $94 \%$ & $60 \%$ & $78 \%$ \\
government subsidies & .84 & .64 & .96 & .75 \\
& $4 \%$ & $31 \%$ & - & $3 \%$ \\
economic activities & $<0.10$ & $<0.10$ & - & $\mathrm{n}=1$ \\
institutions/entrepreneurs & $46 \%$ & $37 \%$ & $20 \%$ & $53 \%$ \\
& $<0.10$ & $<0.10$ & $<0.10$ & .23 \\
& $50 \%$ & $81 \%$ & $50 \%$ & $37 \%$ \\
& 10.10 & .13 & $<0.10$ & .17 \\
& $12 \%$ & $37 \%$ & $30 \%$ & $37 \%$ \\
& .49 & .37 & .91 & .26 \\
\hline & & & &
\end{tabular}


Table 4. Perceived budget competition

\begin{tabular}{|c|c|c|c|c|}
\hline & Belgium & $\begin{array}{c}\text { The } \\
\text { Netherlands }\end{array}$ & Germany & France \\
\hline \multicolumn{5}{|l|}{ NGOS } \\
\hline (1) 'no competition’ and (2) 'little competition’ & $27 \%$ & $18 \%$ & $16 \%$ & $33 \%$ \\
\hline (3) 'moderate competition' & $46 \%$ & $36 \%$ & $32 \%$ & $36 \%$ \\
\hline (4) 'strong competition' & $27 \%$ & $45 \%$ & $52 \%$ & $30 \%$ \\
\hline \multicolumn{5}{|l|}{ Business interests } \\
\hline (1) 'no competition’ and (2) 'little competition’ & $60 \%$ & $58 \%$ & $58 \%$ & $64 \%$ \\
\hline (3) 'moderate competition' & $31 \%$ & $38 \%$ & $30 \%$ & $18 \%$ \\
\hline (4) 'strong competition' & $9 \%$ & $4 \%$ & $12 \%$ & $18 \%$ \\
\hline \multicolumn{5}{|l|}{ Trade unions } \\
\hline (1) 'no competition' and (2) 'little competition’ & $17 \%$ & $12 \%$ & $89 \%$ & $34 \%$ \\
\hline (3) 'moderate competition' & $43 \%$ & $38 \%$ & $11 \%$ & $21 \%$ \\
\hline (4) 'strong competition’ & $39 \%$ & $50 \%$ & $0 \%$ & $45 \%$ \\
\hline
\end{tabular}

Index: Question was formulated as follows: Do you, in finding the resources you need, face 1) no competition from other actors, 2) little competition from other actors, 3) Moderate competition from other actors or 4) Strong competition from other actors.

\section{Table 5. Correlations of staff resources, critical resource dependencies and perceived budget competition with Europeanization (Pearson product moment correlations)}

\begin{tabular}{|c|c|c|c|c|}
\hline & Belgium & The Netherlands & Germany & France \\
\hline $\begin{array}{l}\text { Number of FTE working for the } \\
\text { organization }\end{array}$ & - & - & $-.22(p=.0475)$ & - \\
\hline $\begin{array}{l}\text { Perceived budget competition } \\
\text { (4-point scale) }\end{array}$ & $.22(\mathrm{p}=.0110)$ & $.34(p=.0004)$ & $.37(p=.0006)$ & - \\
\hline \multicolumn{5}{|l|}{ Individual membership } \\
\hline $\mathrm{y} / \mathrm{n}$ & - & - & $.38(\mathrm{p}=.0002)$ & - \\
\hline average budget share & $-.28(\mathrm{p}=.0086)$ & - & - & $.25(\mathrm{p}=.0488)$ \\
\hline \multicolumn{5}{|l|}{ Company membership } \\
\hline $\mathrm{y} / \mathrm{n}$ & $-.20(\mathrm{p}=.0130)$ & $-.34(p=.0004)$ & $-.40(p=.0001)$ & - \\
\hline average budget share & - & - & - & - \\
\hline \multicolumn{5}{|l|}{ Government subsidies } \\
\hline $\mathrm{y} / \mathrm{n}$ & $.37(\mathrm{p}<.0001)$ & $.22(\mathrm{p}=.0199)$ & $.40(p=.0001)$ & - \\
\hline average budget share & $.38(\mathrm{p}=.0014)$ & $.32(\mathrm{p}=.0403)$ & - & - \\
\hline \multicolumn{5}{|l|}{ Economic activities } \\
\hline $\mathrm{y} / \mathrm{n}$ & - & - & - & - \\
\hline average budget share & - & - & - & - \\
\hline \multicolumn{5}{|l|}{ Institutions/entrepreneurs } \\
\hline $\mathrm{y} / \mathrm{n}$ & - & - & - & - \\
\hline average budget share & - & - & - & - \\
\hline
\end{tabular}

Index: The Pearson product moment correlation between ‘average budget share' and 'Europeanization' is only calculated for those organizations depending on a particular resource. Only Pearson product moment correlations significant at the $\mathrm{p} \leq .05$ level are shown. 
Table 6. Importance of policy-sector, scope and Europeanization (Pearson product moment correlations)

\begin{tabular}{lcccc}
\hline & Netherlands & Belgium & Germany & France \\
\hline Scope $=$ scale from 0 to 19 reflecting $\mathrm{n}$ & -.40 & -.27 & -.28 & -.18 \\
policy domains in which an actor is active & & & .40 & .24 \\
\hline 1. competition policies & .50 & .36 & .35 & .30 \\
2. export promotion & .43 & .37 & .24 & .36 \\
3. environmental policy & .25 & .19 & .42 & - \\
\hline 4. consumer policy & .31 & .19 & .28 & - \\
5. industrial policy & .28 & .28 & .23 & - \\
6. research and development & .35 & .30 & - & .19 \\
7. public health & .31 & .17 & .26 & - \\
8. monetary policies and capital markets & - & .17 & - & - \\
\hline 9. agriculture/fisheries & .23 & .17 & .31 & - \\
10. traffic and transport & .34 & - & - & .24 \\
11. foreign and defence policy & - & - & .23 & - \\
12. energy policy & -.20 & - & -.22 & - \\
13. migration- and asylum policy & - & - & - & - \\
14. development cooperation & -.20 & - & - & - \\
\hline 15. cultural and media policies & - & - & - & - \\
16. social security & - & - & - & - \\
17. employment policy & - & - & - & \\
18. labour law policy & - & - & - \\
19. fiscal and tax policy & - & - & - & \\
\hline
\end{tabular}

Index: Only Pearson product moment correlations significant at the $\mathrm{p} \leq .05$ level are shown 


\section{Literature}

Bartolini, S. (2005) Restructuring Europe: Centre Formation, System Building, and Political Structuring between the Nation State and the European Union, Oxford: Oxford University Press. Bennett, R. R. (1999) 'Business Routes of Influence in Brussels: Exploring the Choice of Direct Represenation’, Political Studies 47(2): 240-57.

Beyers, J. (2002) 'Gaining and seeking access. The European adaptation of domestic interest associations’, European Journal of Political Research 41(5): 585-612.

Beyers, J. and B. Kerremans (2007) 'The Press Coverage of Trade Issues. A Comparative Analysis of Public Agenda-Setting and Trade Politics', Journal of European Public Policy 14(2):in press.

Börzel, T. A. (1999) 'Towards Convergence in Europe? Institutional Adaptation to Europeanisation in Germany and Spain’, Journal of Common Market Studies 37(4): 573-96. Bouwen, P. (2002) 'Corporate Lobbying in the European Union: The Logic of Access', Journal of European Public Policy 9(3): 365-90.

Broscheid, A. and D. Coen (2003) 'Business Interest Representation and European Commission Fora: A Game Theoretic Investigation’, European Union Politics 4(2): 165-89.

Bursens, P. (1997) 'Environmental Interest Representation in Belgium and the EU:

Professionalisation and Division of Labour within a Multi-Level Governance Setting'. Environmental Politics 6(4): 51-75.

Coen, D. (1997) 'The evolution of the large firm as a political actor in the European Union', Journal of European Public Policy 4(1): 91-108.

Coen, D. (1998) 'The European Business Interest and the Nation State: Large-firm Lobbying in the European Union and Member States’, Journal of Public Policy 18(1): 75-100.

Constantelos, J. (2004) 'The Europeanization of Interest Group Politics in Italy: Business Associations in Rome and the Regions', Journal of European Public Policy 11(6): 1020-40. Cram, L. (2001) 'Governance 'to Go': Domestic Actors, Institutions and the Boundaries of the Possible’, Journal of Common Market Studies 39(4): 595-618.

Eising, R. (2003) 'Interest Groups: Opportunity Structures and Governance Capacity’, in K. Dyson and K. H. Goetz (eds) Germany, Europe and the Politics of Constraint, Oxford: Oxford University Press, pp. 147-72. 
Eising, R. (2004) 'Multilevel Governance and Business Interests in the European Union’, Governance: An International Journal of Policy and Administration 17(2): 211-45.

Eising, R. and B. Kohler-Koch (2004) 'Interessenpolitik im europäischen Mehrebenensystem', in

R. Eising and B. Kohler-Koch (eds) Interessenpolitik in Europa, Baden-Baden: Nomos, pp. 1175

Fairbrass, J. and A. Jordan (2001) 'Protecting biodiversity in the European Union: national barriers and European opportunities', Journal of European Public Policy 8(4): 499-518.

Goetz, K. (2000) 'European Integration and National Executives: A Cause in Search of an Effect?’ West European Politics 23(4): 210-31.

Gray, V. and D. Lowery (1996) ‘A Niche Theory of Interest Representation’, The Journal of Politics 58(1): 91-111.

Green Cowles, M., J. Caporaso, et al. (eds) (2001) Transforming Europe. Europeanization and Domestic Change, London: Cornell University Press.

Grote, J. R. and A. Lang (2003) 'Europeanization and Organizational Change in National Trade Associations: An Organizational Ecology Perspective', in K. Featherstone and C. M. Radaelli (eds) The Politics of Europeanization. Oxford: Oxford University Press, pp. 225-54.

Hacking, I. (1999) The social construction of what? Cambridge: Harvard University Press. Hanf, K. and B. Soetendorp (eds) (1998) Adapting to European Integration. Small States and the European Union. London: Longman.

Harmsen, R. (1999) 'The Europeanization of National Administrations: A Comparative Study of France and the Netherlands' Governance: An International Journal of Policy and Administration 12(1): 81-113.

Hirschman, A. O. (1970) Exit, Voice and Loyalty. Responses to Decline in Firms, Organizations and States, Cambridge: Harvard University Press.

Hooghe, L. and G. Marks (2001) Multi-Level Governance and European Integration, Lanham:

Roman \& Littlefield.

Kassim, H., B. G. Peters, et al., (eds) (2000) The National Co-ordination of EU Policy. The Domestic Level, Oxford: Oxford University Press.

Knill, C. (2001) The Europeanization of National Administrations. Patterns of Institutional Change and Persistence, Cambridge: Cambridge University Press. 
Kohler-Koch, B. (2005) 'European Governance and System Integration', European Governance Papers c-05-01: http://www.connex-network.org/eurogov/pdf/egp-connex-C-05-01.pdf.

Ladrech, R. (1994) ‘Europeanization of Domestic Politics and Institutions: The Case of France’, Journal of Common Market Studies 32(1): 69-88.

Ladrech, R. (2005) 'The Europeanization of Interest Groups and Political Parties', in S. Bulmer and C. Lesquesne (eds) The Member States and the European Union, Oxford: Oxford University Press, pp. 318-37.

Marks, G. and D. McAdam (1996) 'Social Movements and The Changing Structure of Political Opportunity in the European Union', in G. Marks, F. W. Scharpf, P. W. Schmitter and W. Streeck (eds) Governance in the European Union, London: Sage, pp. 95-120.

Marks, G. and D. McAdam (1999) 'On the Relationship of Political Opportunities to the Form of Collective Action: the Case of the European Union', in D. della Porta, H. Kriesi and D. Rucht (eds) Social Movements in a Globalizing World, London: MacMillan, pp. 97-111.

Michalowitz, I. (2004) 'Lobbying as a Two-Way Strategy: Interest Intermediation or Mutual Instrumentalisation', in A. Warntjen and A. Wonka (eds) Governance in Europe. The Role of Interest Groups, Baden-Baden: Nomos Verlaggesellschaft, pp. 76-93

Olsen, J. P. (2003) ‘Towards a European Administrative Space’ Journal of European Public Policy 10(4): 506-31.

Pfeffer, J. and G.R. Salancik (1978) The External Control of Organizations. A Resource Dependence Perspective, Stanford: Stanford Business Classics

Radaelli, Claudio M. (2003) 'The Europeanization of Public Policy’, in K. Featherstone and C. M. Radaelli (eds) The Politics of Europeanization. Oxford: Oxford University Press, pp. 26-56. Sidenius, N. C. (1999) 'Business, governance structures and the EU: the case of Denmark', in B. Kohler-Koch and R. Eising (eds), The Transformation of Governance in the European Union, London: Routledge, pp. 173-88.

Trondal, J. and F. Veggeland (2003) 'Access, Voice and Loyalty. The Representation of Domestic Civil Servants in EU Committees’, Journal of European Public Policy 10(1): 59-77. Saurugger, S. (2005) 'Europeanization as a Methodological Challenge: The Case of Interest Groups', Journal of European Comparative Policy Analysis 7(4): 291-312. 
Schmidt, V.A. (1999) 'National Patterns of Governance Under Siege’, in B. Kohler-Koch and R. Eising (eds), The Transformation of Governance in the European Union, London: Routledge, pp. 155-172

Schmitter, P.C. and W. Streeck (1999) [1982] 'The Organization of Business Interest. Studying Associative Action of Business in Advanced Industrial Societies’ Discussion paper 99/1. Max Planck Institute for the Study of Societies, Cologne, Germany.

Wessels, B. (2004) 'Contestation Potential of Interest Groups in the EU: Emergence, Structure, and Political Alliances', in G. Marks and M. Steenbergen (eds), European Integration and Political Conflict, Cambridge: Cambridge University Press, pp. 195-215. 


\section{Endnotes}

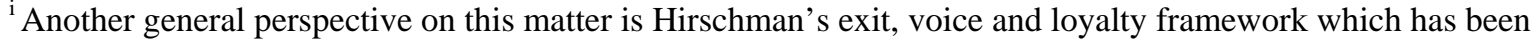
applied by several EU-scholars (Hirschman 1970; Coen 1997 and 1998; Bennett 1999; Trondal and Veggeland 2003; Bartolini 2004; Kohler-Koch 2005). The idea is - in a nutshell - that the process of European integration provides opportunities for domestic interests so that they are able to exit the iron cage of domestic politics and voice their concerns at the European level. As European integration tends to weaken the usefulness of exclusive national strategies, many interests are stimulated to direct their attention to Europe. However, organizations that are highly dependent on the benefits they get from their immediate environment and/or that are highly connected to domestic constituencies, show a low propensity to exit the domestic level. Being Europeanized is therefore typical for groups that offer less direct benefits to their members or that depend less on exchange relations with their constituencies. Also, organizations that depend only weakly for their survival on domestic institutions (for instance, because they receive only a small amount of subsidies from domestic agencies), will more easily transcend national borders. Thus, it is not necessarily the absence or the modesty of key resources that explains the low or high level of Europeanization. The key is that interest groups, whether they are resourceful or not, should be less dependent on resources or benefits they gain from their immediate environment. To put it differently, rather than the amount of available resources available, it is, in Hirschman's framework, the presence or the absence of exit-options at the national level that affects the extent to which organizations are Europeanized (see also Marks and McAdam 1999). ${ }^{i i}$ Our research project also includes public officials and how they interact with interest groups, but because public officials are not directly relevant for the problem we deal with in this paper, we do not pay extensive attention the interviews conducted with them.

iii Because the larger project deals with trade policymaking, we especially focus on sources which list interest groups that are potentially active in this sector. The WTO-website (www.wto.org) contains a number of useful sources ranging from listings of interest groups and civil society organizations attending ministerial conferences, expert meetings, position papers delivered to the WTO and so on. Second, DG Trade of the European Commission has established a Civil Society Dialogue, an open process of consultation to which interest groups may subscribe (http://trade-info.cec.eu.int/civil_soc/intro1.php). Also from this source we retained Euro-level, Belgian, French, German and Dutch actors. Third, we coded all interest groups mentioned in a policy event data set that was developed for the purpose of this project. Fourthly, we added Euro-level, Belgian, French, German and Dutch actors that are listed in the WTO-history project, University of Washington (http://depts.washington.edu/wtohist). All these selected groups were coded on the basis of a number of variables such as type of interests (employers, trade unions, NGOs), policy sector in which a group is active and so on.

${ }^{\text {iv }}$ In addition also 146 representatives of government institutions, parliamentarians and political parties were interviewed, but these interviews are not analyzed in this paper. The same project also includes 139 EU-level interest groups and public officials. There is another aspect of the table that needs to be clarified, namely the fact that the sample size differs considerably from country to country. Especially the bigger sample of Belgium and France compared to the smaller sample for Germany is noteworthy. Our sampling was aimed at a structurally equivalent and comparable sample across countries; this does not necessarily mean samples of an equal size. As such, specific institutional and political conditions within the four countries explain the different sample sizes. Two factors explain the size of the Belgian sample. First, there is the specific nature of the Belgian federation which results in a fairly fragmented interest group system. For instance, whereas in most other countries we find one environmental peak association, Belgium has four environmental peak associations, one for each of the sub-states (Bursens 1997). In addition to this, interest representation by labor unions is quite fragmented with different sectoral and cross-sectoral unions linked to the socialist, liberal and catholic pillars. The fragmentation of the trade union system is even more pronounced for France and explains the larger sample compared to Germany and, to some extent, the Netherlands. In Germany the existence of one big cross-sectoral trade union and its cross-sectoral satellites led to an identification of 15 trade unions of which 13 were sampled. A similar procedure in France led to the identification of 65 trade unions of which only 36 could be sampled.
} 